\title{
Tecnologias de Comunicação, Entretenimento e Cognição na Cibercultura: uma análise comparativa dos seriados $\mathrm{O}$ Incrível Hulk e Heroes ${ }^{1}$
}

Communication Technologies, Entertainment and Cognition in Cyberculture: a Comparative Analysis Between The Incredible Hulk and Heroes TV Series

Fátima Régis

Raquel Timponi

Alessandra Maia

Daniela Almeida

José Messias Santos

Juliana Fernandes

Mariana Aguiar

Renata Silva

\section{Resumo}

O artigo apresenta dados iniciais de pesquisa comparativa entre dois seriados de TV: O Incrível Hulk 1977 (anterior à explosão das tecnologias digitais) e Heroes - 2006 (plena cibercultura). O objetivo da pesquisa é investigar se as transformaçôes que as tecnologias digitais engendraram nos sistemas de mídia exigem novas competências cognitivas para a fruição de seriados de TV.

Palavras-chave: Cibercultura, Entretenimento, Seriados de TV, Cognição, Tecnologias de Comunicação.

\section{Abstract}

This article presents the first output of a comparative research between two TV series: The Incredible Hulk1977 (before digital technology boom) and Heroes - 2006 (during cyberculture age). The research aims to investigate if differences engendered by digital technologies in media systems requires new cognitive abilities to watch the contemporary TV series.

Keywords: Cyberculture, Entertainment, TV series, Cognition, Communication Technologies. 


\title{
Tecnologias de Comunicação, Entretenimento e Cognição na Cibercultura: uma análise comparativa dos seriados $\mathrm{O}$ Incrível Hulk e Heroes ${ }^{1}$
}

\begin{abstract}
Fátima Régis I fregis@uerj.br Professora Doutora da Graduação e da Pós-Graduação da FCS-UERJ.

Raquel Timponi I raquel.timponi@gmail.com Mestre em Comunicação pela UERJ.

Alessandra Maia I ale.led@gmail.com Estudante do Curso de Jornalismo da FCS-UERJ.

Daniela Almeida I daniela.msalmeida@gmail.com Estudante do Curso de Jornalismo da FCS-UERJ. José Messias Santos I jmessias.santos@gmail.com Estudante do Curso de Jornalismo da FCS-UERJ. Juliana Fernandes I julianafernandesrp@yahoo.com.br Estudante do Curso de Relações Públicas da FCS-UERJ.

Mariana Aguiar I marianafaguiar@gmail.com

Estudante do Curso de Relações Públicas da FCS-UERJ.

Renata Silva I rezoca@hotmail.com Mestranda do Programa de Pós-Graduação em Comunicação da FCS-UERJ.
\end{abstract}




\section{Introdução}

O modo como as Tecnologias de Informação e de Comunicação (TIC) possibilitam a transposição de meios e linguagens para a base digital tem deflagrado uma série de transformações no sistema de mídias e de entretenimento contemporâneo. Vários pesquisadores têm defendido que essas transformações estimulam uma capacitação cognitiva em seus usuários (JOHNSON, 2005; ANDERSON, 2006; JENKINS, 2008). No entanto, em sua maioria, esses estudos adotam uma abordagem macro-social, deixando uma lacuna sobre quais são essas habilidades cognitivas e como atuam sobre as práticas comunicativas. Em nosso estudo adotamos uma perspectiva "micro" por meio da realização de uma pesquisa empírica, possibilitando a investigação dos produtos culturais em suas especificidades.

Este artigo apresenta os resultados preliminares de uma parte da pesquisa "Tecnologias de comunicação, entretenimento e habilidades cognitivas na cibercultura", desenvolvida pelo Grupo de Pesquisa "Comunicação, Entretenimento e Cognição" do Programa de Pós-Graduação em Comunicação da UERJ pela professora-orientadora, uma mestre, uma mestranda e cinco estudantes de iniciação científica.

O objetivo principal da pesquisa é mapear se há, e em caso positivo quais são, as mudanças nas habilidades cognitivas requeridas para as práticas de comunicação e fruição de produtos de entretenimento nas últimas três décadas. Essas mudanças serão investigadas por meio de análise comparativa entre produtos culturais (seriados de TV) 3 produzidos nas décadas de 1980 (fase inicial da cibercultura / antes da explosão das mídias digitais), 1990 (explosão da Internet e ciberespaço) e 2000 (plena cibercultura).

Os seriados de TV foram selecionados a fim de se evidenciar como as mídias novas e antigas se recombinam no cenário da cibercultura. Os făs do seriado Lost (2004-atual), por exemplo, contam com uma complexa rede de fóruns, listas de discussão, comunidades virtuais e blogs e websites que servem como fonte de divulgação de novidades, revelaçóes e teorias sobre os mistérios da trama do seriado.

A importância de destacar os pontos de interseção entre mídias "novas" e "antigas" deve-se a um motivo preciso. Nos estudos sobre a cibercultura, o discurso hegemônico para explicar a revolução gerada pela Internet se fundamenta em uma suposta oposição entre a Internet e os Meios de Comunicação de Massa. $\mathrm{O}$ argumento é bastante conhecido: ao contrário do modelo massivo e autoritário da comunicação de massa, a comunicação em rede constituiria um novo modelo de produção, divulgação e distribuição intrinsecamente democrático, o modelo todos-todos (LÉVY, 1999), no qual artista e público alternam papéis. Um dos principais problemas deste argumento é classificar os meios de comunicação de massa e a comunicação mediada por computador como dois tipos de processos de comunicação distintos, separados no tempo e no espaço, sem pontos de interseção.

A escolha dos seriados de TV é precisamente para buscar entender de que modo as tecnologias digitais e a revolução social, estética e econômica em curso 
reconfiguram, inclusive, os produtos culturais anteriores devido aos processos de remixagem (MANOVICH, 2005) e de remediação (BOLTER \& GRUSIN, 1998).

O trabalho é composto de três etapas. A primeira (já concluída) foi de levantamento e leitura da bibliografia de referência. Foi feita uma revisão da bibliografia, principalmente nas sub-áreas de cultura de massa, entretenimento popular, cibercultura, filosofia e ciências cognitivas. A segunda etapa foi dedicada à criação de categorias e critérios para a análise comparativa. A partir de uma investigação preliminar e exploratória sobre diversas competências descritas por autores da cibercultura, foram elaboradas as seguintes categorias de análise cibertextualidade, logicidade, sociabilidade, sensorialidade e criatividade. O processo de desenvolvimento dessas categorias foi descrito no projeto de pesquisa "Tecnologias de comunicação e novas habilidades cognitivas na cibercultura" (RÉGIS, 2008). A terceira etapa da pesquisa (em andamento) consiste da coleta, descrição e análise dos seriados de TV (e futuramente, games) selecionados para investigação.

Este artigo apresenta os resultados das investigaçóes iniciais desta pesquisa. Foram analisados seriados do mesmo gênero (aventura e ficção), com mesma temática (heróis humanos) e endereçados a uma mesma faixa de público (adolescentes e adultos na faixa de 25 a 45 anos). As séries escolhidas foram "O Incrível Hulk" (1977) e "Heroes" (2006).

\section{Cognição e categorias de análise das competências cognitivas}

Pela tradição da filosofia ocidental, o processo cognitivo é tarefa prioritária, quando não exclusiva, do pensamento sem correlação com as experiências sensório-motoras, as relações sociais e os objetos técnicos. A retomada das idéias de alguns filósofos ajuda a ilustrar a questão. Em Platão, o acesso ao conhecimento verdadeiro no Mundo Inteligível ocorre por meio das reminiscências. Antes de nascer, as almas contemplam as essências e observam o bem e todas as virtudes em sua forma mais pura. Após encarnar, a alma tende a esquecer todo o conhecimento contemplado. É preciso desligar-se do mundo terreno para recuperar as reminiscências: o conhecimento resultante da contemplação das essências que é retido pela alma antes de encarnar no corpo material e mortal. Em Descartes, embora a garantia do conhecimento seja dada pela existência de Deus, é a alma que realiza todo o processo de atividade mental e representacional. Para realizar sua tarefa a contento a alma deve livrar-se das percepçóes e sensaçóes provenientes do mundo sensível. O processo de conhecimento é atributo exclusivo da alma que opera no interior do sujeito, isolada do mundo sensível e técnico. Em Kant, o processo de conhecimento ocorre por meio das intuiçóes e conceitos, produtos das faculdades apriorísticas do conhecimento sensibilidade e entendimento. Na equação do conhecimento kantiana o objeto e o mundo exterior - que só podem ser conhecidos enquanto fenômenos - são completamente subjugados à razão do sujeito do conhecimento.

No século XX, estudiosos de áreas como filosofia, inteligência artificial e ciências cognitivas (DENNETT, 1996; LAKOFF \& JOHNSON, 1999; CLARK, 2001; CLARK, 2001) se dedicam a modificar essa tendência. Esses 
pesquisadores entendem que a mente é o resultado de um longo processo evolutivo que envolve as relaçóes entre corpo e cérebro e suas interaçóes com o ambiente ao longo da história biológica e cultural do indivíduo.

Por esta nova perspectiva, os indivíduos têm suas açóes acopladas ao mundo; suas decisôes são contextualizadas, ancoradas em situaçôes concretas e se apóiam em todos os nossos sentidos e habilidades. E isso não é tudo. Pesquisadores como Donald Norman e Andy Clark incluem no processo cognitivo as interaçôes com outros indivíduos e com os objetos técnicos. Norman denomina de artefatos cognitivos qualquer ferramenta que auxilie a mente (1993, p. 4) o que inclui tanto artefatos materiais, como o papel, o lápis, a calculadora, o computador, quanto artefatos mentais, como a linguagem, a lógica e a aritmética.

Com base nesse conceito de cognição, as práticas de comunicação e de entretenimento estimuladas pelas tecnologias de informação e de comunicação (exploração de ambientes, busca de informaçóes, aprendizado de novas linguagens e interfaces, produção colaborativa de conteúdos) ${ }^{4}$ são classificadas como cognitivas.

Alinhada com esse conceito de cognição e com a proposta de criar uma metodologia de investigação, a pesquisa agrupa as competências cognitivas em cinco categorias de análise: cibertextualidade, sensorialidade, logicidade, criatividade e sociabilidade.

As cinco categorias são o ponto de partida para o estudo das competências que estariam sendo requeridas e estimuladas nas práticas comunicativas do entretenimento contemporâneo. Essas categorias operam integradas entre si e algumas habilidades atuam nas interseçóes das mesmas, mas para fins de aplicabilidade da pesquisa, precisam ser descritas separadamente.

A Cibertextualidade é uma junção do conceito de Cibertextos de Aarseth com a noção de Intertextualidade de Eco. Compreende o conjunto de características das TIC que ao possibilitar a hibridação de meios, linguagens e textualidades, afetam a produção de textos, sua leitura e participação do leitor. Aarseth defende que as mídias digitais demandam um esforço não-trivial, envolvendo habilidades sensoriais e lógicas. A cibertextualidade refere-se também aos textos que citam intencionalmente um outro produto cultural, estimulando a conexão de diferentes produtos culturais e os processos de leitura ergódica (Aarseth, 1997), produção e associação de conteúdo, diferenciados em relação à leitura linear.

A Sensorialidade examina como, ao reunir vários meios simultaneamente e combinar linguagens e textualidades distintas, os novos gadgets (aparelhos celulares, Ipods, DVDs, capacetes de realidade virtual, plataformas de videogames) oferecem tecnologias que despertam diversos sentidos e desafiam as capacidades sensoriais, perceptivas, táteis, imersivas e de atenção (telas sensíveis ao toque, habilidades de visualização em telas minúsculas e divididas, manuseio de diversos tipos de joysticks e aparelhos de controles remotos; atenção e percepção seletivas para localizar a informação desejada).

A Logicidade se refere ao estímulo a habilidades mentais tradicionalmente ligadas à lógica e resolução de problemas. A esta categoria pertencem as 
tarefas que aprimoram o caráter lógico, tais como: tomada de decisão, análise e reconhecimento de padróes. Neste item estão também as atividades associativas indispensáveis à formação da enciclopédia intertextual e de orientação espacial do usuário.

A Sociabilidade se refere ao modo como as tecnologias digitais, ao favorecer a produção de conteúdo, incentivam que o indivíduo esquadrinhe as diversas mídias em busca da informação desejada e, engendram um processo de colaboração entre indivíduos que se reúnem em comunidades virtuais, listas de discussão, blogs para buscar, produzir e partilhar informaçóes adicionais sobre seus produtos culturais favoritos.

Essa "participação" dos espectadores se reflete na criação de redes colaborativas, ou seja, o conjunto de meios de comunicação utilizados pelos usuários para trocar informaçôes sobre seus produtos midiáticos favoritos. Essa rede não é invenção da cibercultura. Há décadas que filmes, seriados de televisão, livros e histórias em quadrinhos contam com cadernos culturais em jornais, revistas de entretenimento, documentários que comentam episódios, estruturas narrativas e motivação de personagens. Mas, o ápice dessas redes da mídia encontra seu suporte na internet cujos blogs, sites, listas de discussão, softwares colaborativos, redes de relacionamento tornam-se recursos complementares de cognição dos programas e nas mídias móveis (celulares, Ipods).

A Criatividade se dedica às habilidades que estimulam a criação e participação nas atividades colaborativas na rede. Investiga o estímulo à intervenção nos produtos por parte dos usuários, seja pela criação de obras inéditas, seja pela criação por meio de mixagens, fanfictions, paródias, mashup e spoofs. Essa categoria envolve a construção social de conhecimento por meio dos recursos de blogs, redes $\mathrm{p} 2 \mathrm{p}$ e redes de relacionamento que constituem a chamada Web 2.0 (O'REILLY, 2005).

\section{Análise comparativa dos seriados Heroes e Hulk}

As categorias descritas acima se subdividem em variáveis que serão efetivamente aplicadas para fins de investigação. A seguir são descritas as variáveis e sua aplicação na análise preliminar dos seriados Heroes (2006) e Hulk (1977).

\section{Cibertextualidade}

A categoria Cibertextualidade está subdividida nas variáveis: 1) estrutura da narrativa (composta por número de personagens, número de tramas e núcleos de personagens - enredos múltiplos - e articulação entre os núcleos: relaçôes sociais e arco dramático); 2) recursos metalingüisticos e hipermidiáticos composta de citaçóes, auto-referências e referências a produtos originários de outras mídias.

Quanto a primeira variável, estrutura da narrativa, o arco dramático seria o esqueleto de uma história maior, com tramas paralelas que vão se construindo ao longo dos episódios. O arco dramático de Heroes envolve muitos protagonistas, os personagens "heróis", que têm como o objetivo central unir seus poderes para salvar o mundo. Já em Hulk, num primeiro momento, pode-se pensar que não existe uma história única ao longo dos episódios; porém o arco 
gira em torno de dois eixos: a busca pela cura da mutação genética e o conflito pessoal de David Banner entre o instinto animal e a racionalidade humana.

Geralmente o arco dramático é composto de enredos múltiplos, isto é, várias tramas. Em Heroes, os primeiros núcleos são apresentados à primeira vista de forma desconexa. Mas, com o passar dos episódios, os núcleos vão se entrelaçando e as histórias se tornando mais complexas, repletas de relaçóes sociais entre os personagens, todos protagonistas. Inicialmente coadjuvantes, aos poucos os personagens ganham espaço na trama (como é o caso da menina Molly que aparece sem destaque e depois desaparece, mas é essencial para encontrar outros heróis). Se no início da primeira temporada de Heroes observa-se a separação das cenas em núcleos diferentes e o espectador tem a impressão de que cada um seria um gênero cinematográfico diferente (ação, drama, aventura, ficção), com o passar dos episódios fica difícil realizar essa mesma distinção, pois as tramas possuem um pouco da característica de cada gênero.

Ao contrário de Heroes, Hulk não possui tantos personagens fixos. A narrativa se estrutura em torno do protagonista (David Banner) e de personagens avulsos cuja única função é dar suporte à narrativa de um determinado episódio. Exceto pela participação constante do personagem Jack McGee, um repórter que persegue o monstro. No entanto, existe a preocupação em apresentar os personagens e as informaçóes de modo geral. $\mathrm{Na}$ abertura de cada capítulo, há uma contextualização da história e do perfil do protagonista para situar o espectador do porquê da transformação do médico em monstro. Num seriado atual essa referência só seria utilizada em um episódio.

Quanto à forma, a narrativa de Hulk segue os padróes dos seriados da época, que é predominantemente linear e explicada em detalhes. Mas ao mesmo tempo, já se pode observar, no primeiro episódio, o uso do flashback para explicar a construção psicológica do Dr. David Banner e nos capítulos seguintes quando há necessidade de se recordar algum fato importante.

Já o enredo de Heroes é fragmentado e não linear. Há a mistura temporal de presente, passado e futuro, sem nenhum indicativo, enquanto que na linguagem clássica de cinema e TV eram utilizadas imagens embaçadas, em preto e branco e/ou eco na voz. Várias açôes ocorrem simultaneamente, há a alternância dos núcleos dos personagens pela montagem. Cabe ao espectador interpretar e ligar as informaçôes que não fazem sentido ou se tornam contraditórias, porque estão em tempos diferentes. Um exemplo típico em Heroes é o momento em que Hiro e Ando vão para Nova Iorque após a explosão da bomba atômica e vêem os destroços da cidade. Em seguida voltam no tempo e, nesse trecho, segue-se a narrativa de forma linear. Os objetos em cena ganham importância para a construção mental da linearidade da história, como, por exemplo, o carro que Hiro e Ando alugam, similar ao mostrado nos quadrinhos, elemento metalingüístico que instrui suas açóes futuras.

Mesmo esses recursos de auxílio ao espectador, intervençôes temporais, como o congelamento de cenas para se passar mensagens do futuro no presente, complexificam o arco dramático. Isso se tornou possível porque o espectador foi acostumado ao longo do tempo a acompanhar as narrativas de tal forma 
que hoje não são necessárias tantas explicaçóes da história para o entendimento completo da trama. Assim, não há tanta didática nos seriados das últimas décadas como nos clássicos da cultura de massa. As referências mais explícitas em Heroes são: a cidade e o nome dos protagonistas no início dos episódios, isso devido ao aumento do número de personagens no decorrer da série. Somente a primeira parte dos capítulos contém uma espécie de resumo dos principais acontecimentos do episódio anterior, explicando até um pouco mais do que o capítulo precedente conta (supóe que o espectador tenha interpretado os fatos) e a partir de algumas cenas anteriores desenvolve a história ainda mais.

Já nos seriados convencionais é comum o uso constante de setas indicativas do que acontecerá na trama, tais como a inserção de uma música de suspense para indicar uma cena de tensão, ou a filmagem de planos em close de um objeto que revela ser a arma de um crime, entre outros. Esse recurso, segundo Steven Johnson (2005) é chamado de seta intermitente, uma indicação clara na narrativa como uma placa luminosa indicando que algo acontecerá.

Em Hulk, os movimentos de câmera indicam a maioria das setas intermitentes ${ }^{5}$. Na primeira cena do quinto episódio, 747 , na qual surgem os vilóes, o diretor faz questão de mostrar em close a pistola acompanhada da trilha sonora sinalizando que algo de ruim irá acontecer. Já em Heroes, o que se pode perceber são "pistas falsas" - assunto tratado mais adiante no artigo.

Outro fator que pode ser avaliado, ainda com relação a essa primeira variável é a complexidade psicológica dos personagens. Diferentemente dos heróis clássicos que têm um caráter engessado como bom ou mau, em Heroes a personalidade, que raramente é linear, é esboçada ao longo dos episódios. Assim, os poderes dos personagens e sua real função são explicitados aos poucos, o que ocasiona mudanças no rumo da trama. O cotidiano do super-herói é mesclado à vida familiar com todos os seus conflitos (internos e externos - vários heróis utilizam seus poderes em benefício próprio, como Hiro no cassino, que pára o tempo para ganhar o jogo), portanto, sem o estereótipo de perfeição e bondade. Um exemplo é o Sr. Bennet que, primeiramente, se mostra um homem misterioso e passa a impressão de ser um possível vilão. No decorrer dos episódios pode-se pensar que Bennet tem algo a ver com a morte do professor (ele seqüestra vários heróis por conta de seu trabalho). Já em um outro momento, apresenta um amor de pai, em proteção de sua filha Claire, mesmo que por métodos não louváveis (ameaça o zagueiro de futebol do colégio da filha). Ao mesmo tempo, quando se pensa que um personagem possui características de "bonzinho", como Peter Petrelli, no entanto as coisas ruins acontecem com ele. O não conhecimento do uso de seu poder ocasiona a explosão nuclear.

$\mathrm{Na}$ segunda variável da categoria cibertextualidade estão os recursos metalingüísticos e hipermidiáticos, compostos das citaçôes diretas, das auto-referências do seriado e das referências externas, que exigem um conhecimento cultural prévio do espectador para que entendam o contexto.

Embora o seriado Hulk tenha poucas citaçôes, há referências a outras produçôes da televisão, do cinema e da literatura. A própria concepção da série já remete a narrativas de ficção científica, como o monstro do Dr. Frankenstein, 
do livro de Mary Shelley, e o Sr. Hyde, contraparte do Dr. Jekyll em "O médico e o monstro". Stan Lee, criador do personagem, declarou ter se inspirado nos dois clássicos para desenvolver Hulk. A exemplo disso, no episódio piloto, a cena em que o protagonista encontra uma garota perto do lago é análoga a outra cortada da versão original de Frankenstein no cinema.

Nota-se que as citações em Hulk são mais diretas e de fácil entendimento. Muitas delas são explícitas como no episódio em que um coadjuvante fala sobre o filme Casablanca ou quando o protagonista cita o Dr. Jekyll.

Já o seriado Heroes realiza inúmeras citaçóes em cada episódio, além das referências externas e internas constantes que deixam a trama cada vez mais complexa.

Sabe-se que, muitas vezes, a cultura interfere na tradução e no entendimento das citaçôes como um todo. Um exemplo é a alusão que o personagem Nathan faz à imagem do irmão do presidente Bill Clinton, dos EUA. Como Nathan está numa situação similar à política dos EUA (é candidato a um cargo público, no caso o de senador, não seria prudente que os problemas pessoais de um familiar o prejudicasse), fala para o irmão Peter não ser como Roger Clinton, a ovelha negra da família (Roger tinha cometido crimes e tinha problemas com drogas) no ano da eleição de seu irmão. Peter não usa drogas, mas tenta pular de um prédio, pois em seus sonhos sempre se via voando. Se o seriado se passasse no Brasil, provavelmente este link não seria feito já que, muitas vezes, as citaçôes são locais, características de alguma regiáo específica de um país. Assim, durante a tradução essas citaçóes geralmente são retiradas, como foi feito neste caso para a versão legendada em Português, pois o público poderia não entendê-la. Outras citações podem atingir um público mundial, quando remetem a ícones da música ou a filmes clássicos, por exemplo.

Em Heroes, há também uma série de referências externas, o que torna os episódios mais interessantes e leva o espectador a buscar novas informaçóes e a investigar as metáforas da trama com base em contextos externos. $\mathrm{O}$ relógio que Mohinder vê quando assiste a reconstituiçáo da morte de seu pai, o professor, está presente em uma das cenas na casa Sylar (referência interna). $\mathrm{Na}$ cena de um episódio bem anterior, na casa antiga do Sylar há um monóculo que o relojoeiro usa. $\mathrm{O}$ relojoeiro aqui é uma referência externa ao personagem Dr. Manhattan dos quadrinhos Watchmen, antes um relojoeiro e o herói mais poderoso. $\mathrm{O}$ tema da mutação, que provém dos X-men, também é um exemplo desse recurso utilizado inúmeras vezes no roteiro.

Em Hulk, por sua vez, as referências externas apontam para diferentes assuntos que vão desde o contexto histórico de determinada época até termos científicos. Ao contrário de Heroes, em que as referências são menos explícitas, em Hulk há um cuidado em garantir a compreensão do telespectador. Ao se referir à "mitocôndria", a médica Elaina Marks explica: "elas são responsáveis por tornar o açúcar em energia”. Uma alusão ao contexto da época é quando o protagonista fala da atriz Farrah Fawcett, envolvida com escândalos nos anos de 1970.

As auto-referências em Heroes estão mais inteligentes. Um exemplo é quando Peter fala que completou a pintura de Isaac, adquirindo seu poder, 
cena apenas relatada. Tal recurso pode ser uma opção para o desenvolvimento de narrativas paralelas em mídias alternativas. Assim as próprias auto-referências já estão sendo montadas sob um planejamento para o complemento de informaçóes com conteúdo disponibilizado em mídias alternativas, seguindo o conceito de Henry Jenkins de transmídia (2008). Por exemplo, existe o produto das histórias em quadrinhos de Heroes, que não é unicamente a transposição da trama central para a revista. A história em quadrinhos de Heroes fora do seriado, conta casos paralelos de personagens secundários. Com relação ao tempo disponível em cada suporte para desenvolvimento da história, o mercado atual é mantido através de inúmeros produtos em diferentes mídias. A temporada de uma série só é colocada à disposição para venda ou aluguel após ser totalmente veiculada na televisão norte-americana. Apesar de que, atualmente, o espectador tem a opção de baixar o produto via Internet.

O recurso da metalinguagem por sua vez, também é outro ponto marcante no seriado. A mistura de linguagens está presente na trama pela mescla de informaçôes em diferentes suportes dentro do seriado, tais como dados vindos da pintura e da história em quadrinhos de Isaac, que determinam as açóes de Hiro e Ando no presente.

A metalinguagem em Hulk é mais sutil. Como parte do esquema de lançamento comercial, alguns episódios foram compilados nos filmes "O Incrível Hulk", "O Retorno do Incrível Hulk", "O Julgamento do Incrível Hulk" e a "A Morte do Incrível Hulk". O primeiro lançado antes da série como um piloto-teaser e os outros após seu fim. Os três últimos, publicados seis anos após o encerramento da série, são considerados uma continuaçáo do arco dramático. Além disso, da mesma forma como esses filmes vieram do seriado, a própria série vem dos quadrinhos. O Incrível Hulk foi criado em 1962 por Stan Lee e Jack Kirby e o seriado de 1977 incorporou apenas alguns elementos da trama principal.

Assim, a cibertextualidade permite observar que Heroes envolve maior esforço de atenção e memória do espectador, seja pela interpretação de referências externas, pela organização da linha cronológica da história em sua mente ou ainda pela busca de informaçóes de referências e citaçóes a outros produtos.

\section{Sensorialidade}

Já a segunda categoria sensorialidade trabalha com os diversos sentidos do espectador que hoje são exigidos em diferentes suportes, tais como a possibilidade de se assistir a um seriado via Ipod, na tela do celular ou de estar conectado a inúmeros veículos simultaneamente.

Os seriados atuais exigem uma exploração visual atenta dos cenários, além da lógica para ligar as pistas dadas ao longo do enredo. Uma série formatada nos padróes convencionais (como Hulk), com narrativa linear e guiada por setas intermitentes, é de fácil compreensão e não exige tanta atenção. Já em seriados como Heroes, várias cenas não partem de um início. As imagens aparecem como um mosaico de informaçóes que o espectador "pega” pela metade (como se já estivessem ocorrendo há um tempo). Em alguns momentos, o espectador pode ter a impressão de que há "peças" faltando na história, isso 
porque o novo modelo narrativo não utiliza a explicação minuciosa das açôes. Para captar todas as informaçóes é preciso que o telespectador assista parando o DVD ou reveja várias vezes a mesma cena à procura de pistas. $\mathrm{E}$ ainda assim, a cada vez que revê pode focar a atenção num outro detalhe importante que passou despercebido num primeiro momento.

\section{Logicidade}

A terceira categoria realiza a exploração da logicidade, pela articulação das cenas dos episódios. Apesar de habilidades como raciocínio lógico e capacidade associativa freqüentemente serem relacionadas aos games e outras mídias, muitas vezes elas estão relacionadas à percepção e atenção do espectador em captar e reunir as pistas audiovisuais dos cenários, juntar as informaçóes de conteúdo, como num jogo investigativo.

Em Heroes cabe ao espectador focar-se na exploração dos cenários, procurando pistas para a explicação dos crimes de Sylar contra os heróis, ou o que levou as pessoas a apresentarem poderes sobrenaturais, a analisar os fatores comuns que todos os heróis possuem, etc. Um exemplo de pista que trabalha com a atenção e a lógica do espectador e está presente desde o início da trama é o símbolo do DNA pela metade, que aparece em diferentes cenas e núcleos de personagens.

O seriado Hulk, apesar de ser da década de 70, também faz uso de pistas amenas que se tornam explícitas ao longo do episódio. A diferença é que Hulk não dispõe as pistas em diferentes contextos. A opção para a construção didática da informação e da lógica da história é o uso da repetição de uma mesma cena diversas vezes no mesmo episódio. $\mathrm{O}$ objetivo é dar ênfase a algum acontecimento ou dado importante para a compreensão dos fatos. Apesar de num primeiro momento a informação ser mais amena, devido à repetiçáo excessiva, acaba por se tornar uma seta indicativa. No episódio "Culpas, modelos e crimes", no qual o protagonista se depara com um assassinato, a verdadeira culpada é mostrada quatro vezes ao lado do marido da vítima. A repetição também pode ser percebida na fala de personagens e não somente por meio de imagens. Um exemplo disso acontece no episódio "O último assalto", no qual o protagonista avisa ao boxeador Rocky que ele está sendo usado como traficante de drogas. Logo em seguida, Rocky é chamado por seu chefe e o espectador tem a constatação, já que este entrega um pacote suspeito.

Outro uso relacionado à construção lógica da história é o de pistas falsas. Pode-se observar que elas são responsáveis por manter o interesse do espectador na história, pela possibilidade de a trama tomar um rumo não imaginado. Em Heroes são várias as pistas falsas. A maneira com que as informações são apresentadas leva o espectador a pensar na possibilidade de Ted Sprague (homem radioativo) ser o responsável pela explosáo em Nova Iorque no futuro. Mais à frente, o próprio Ted acredita ser o culpado. Contudo, quem ocasiona a explosão é Peter Petrelli, o mocinho (ele adquire os poderes de Ted, mas não consegue controlá-los).

Outro ponto que desperta curiosidade é o mistério construído pelos próprios personagens, que também tem a ver com a logicidade. Um exemplo é quando o Sr. Bennet esconde que Claire seja sua filha, diz que a adotou e 
contrata supostos pais biológicos. $\mathrm{O}$ espectador desconfia que não sejam seus pais, pois quando saem da casa de Bennet perguntam se deu tudo certo, como se tivessem algo a esconder.

Nesse aspecto, pode-se considerar que as informações não são tão explícitas como as de séries da década de 70. A grande diferença é que as tramas do cinema clássico o espectador sabe o que acontecerá no futuro e torce para que o personagem descubra o que fazer. Já nos filmes e seriados atuais existem dicas inteligentes. Muitas vezes alguns personagens têm conhecimento de alguns fatos ou possuem uma informação extra que falta para o espectador. $\mathrm{O}$ público assim deve inferir acontecimentos e o envolvimento dos personagens nos enredos múltiplos pela lógica. Um exemplo é o da ex-vizinha do professor, Eddain, que, após se tornar amiga de Mohinder, parece esconder algo. Porém, posteriormente ela faz uma ligaçáo para o Sr. Bennet, o homem que persegue Mohinder, o que dá entender que ela trabalha para ele.

\section{Sociabilidade}

Quanto à categoria da sociabilidade, ao se realizar a análise de Hulk, há que se considerar que nos anos 1970 e 1980 os fã́s não contavam com os suportes de interação atuais. A série ficava restrita a fã clubes, fanzines e outros impressos dedicados ao assunto. Como exemplos, é possível citar o fanzine "O Gigante Verde", que abordava o personagem Hulk como tema principal e o universo Marvel em segundo plano, além do periódico americano "The Hulk" que reunia entrevistas e comentários a respeito do personagem, inclusive sobre a série. Outro item importante da época era o álbum de figurinhas do protagonista, que, através da troca, estimulava o debate e a sociabilidade entre os interessados no assunto. Vale a pena destacar que todos esses meios de interação exigiam certa disponibilidade por parte dos fầs - financeira, de tempo, entre outros - algo não tão necessário hoje em dia devido às facilidades que a internet, por exemplo, proporciona na troca de informaçóes e curiosidades. Logo, o número de pessoas dispostas a se socializar desta maneira era inferior ao que encontramos atualmente em séries como Heroes.

Em Heroes, encontra-se uma rede mais ampla e complexa no que diz respeito à sociabilidade. Com o advento das redes virtuais, o acesso aos fóruns de discussão foi facilitado e a participação dos usuários tornou-se diferenciada. Um exemplo é a comunidade no site de relacionamentos Orkut sobre a série, em que em uma mesma página pode reunir os mais diferentes usuários, o que inclui desde o fã até um espectador ocasional. Outros exemplos serão dados na categoria de criatividade.

A digitalização dos suportes e o surgimento das novas mídias têm provocado uma reformulação nas formas de produção, distribuição e consumo dos produtos. Henry Jenkins (2008) afirma que os consumidores estão assumindo o papel de produtores, desenvolvendo conteúdos por conta própria, e, dessa forma, a indústria se aproveita das criaçôes dos fấs para lançar novos itens.

Os produtores de Heroes utilizam o recurso transmidiático para a disponibilização de seus conteúdos. A transmídia consiste no complemento de informaçóes da trama principal, por meio de histórias paralelas em diversas mídias 
diferentes. Esses conteúdos distribuídos não são essenciais para o entendimento geral da trama; funcionam como um bônus de informação. Como veículos transmidiáticos oficiais de Heroes, estão: o site da personagem Samantha (alterego de Niki), que manda e-mails para os usuários; o site de marketing viral da fábrica de papéis Primatech da série, além de uma extensão da série na internet (Heroes: Evolutions), criada para explorar o universo dos Heróis e fornecer informaçóes sobre a mitologia da série. Outras oficiais, como revistas, websódios, games, roupas, mercadorias e a histórias em quadrinhos dos personagens disponíveis para visualização na internet e os próprios episódios para download no site oficial do seriado.

\section{Criatividade}

E, por fim, muito ligada à categoria da sociabilidade está a categoria da criatividade, possibilitada agora aos fâs e que tem interferido em todo o processo de produção da indústria. Diversos veículos que possibilitam a interação dos internautas com a série Heroes, tais como: o site de formato wiki (<http://heroeswiki.com/>), o MySpace dos personagens (<http://www.myspace.com/clairebennet>), os jogos online (<http://www.nbc.com/Heroes/games/quiz.shtml〉) e o projeto de uma série paralela, "Heroes: Origins", na qual o telespectador pode escolher os personagens que devem ir para o seriado principal. No Brasil, o Universal Channel também criou um blog específico da série (http://blog. uc.globo.com/heroes/). À parte dos meios oficiais, os fâs também podem produzir maneiras alternativas de discussão e divulgação de informaçôes através de sites como o Youtube, por meio do qual qualquer um pode participar (<http://www.youtube.com/watch?v=XjVdzIg9nEM\&feature=fvst $>$ ) e o site 9th Wonders! (<http://www.9thwonders.com>), o fä-clube virtual da série.

Mas as séries atuais não são as únicas afetadas pelas novas tecnologias. É preciso ponderar que, atualmente, os últimos filmes remakes do original The Incredible Hulk (1978) nos anos 2000 (Hulk, em 2003, e The Incredible Hulk, em 2008), fizeram emergir novas produções via internet. Isso possibilitou que espectadores que não tinham conhecimento sobre o seriado dos anos 70 de Hulk pudessem chegar ao produto original, através das buscas pela internet (O seriado Incrível Hulk, por exemplo, possui uma comunidade própria no Orkut <http://www.orkut.com.br/Main\#Community.aspx?cmm=1601818>), ou mesmo dar novos usos para o seriado, como montagens de clipes (fotomontagem) com áudio e legenda do seriado de Hulk (1977) via vídeos no Youtube (<http://www.youtube. com/watch?gl=BR\&hl=pt\&v=GF2ppLYH6l A ). Assim, observa-se a possibilidade de transformar um produto de outro período em transmidiático, pelas mãos do público, via rede.

\section{Considerações finais}

Ao fazer uma análise comparativa entre os seriados Hulk (1977) e Heroes (2006), pode-se notar que diversos recursos complexificaram a narrativa e as formas de fruição dessas obras. Desde o aumento do número de personagens, a sua construção psicológica e das relações sociais entre os mesmos, até se alcançar elementos "extra-história", com os produtos transmidiáticos. Por esse 
motivo, essa análise, ainda preliminar, parece apontar para o fato de que algumas competências cognitivas têm sido estimuladas e desenvolvidas pelos seriados de televisão.

Assim, a pesquisa diverge tanto da lógica do entretenimento popular visto como pura diversão e relaxamento mental quanto da tradição filosófica que reduz cognição a processos conscientes e lógicos. Para a fruição dos produtos de entretenimento são necessárias diversas competências cognitivas, incluindo as competências intelectuais, como raciocínio e lógica, as competências sensoriais, como atenção e percepção, e as competências sociais e criativas.

\section{Notas}

${ }^{1}$ Este artigo foi apresentado no GP Cibercultura, IX Encontro dos Grupos/Núcleos de Pesquisas em Comunicação, evento componente do XXXII Congresso Brasileiro de Ciências da Comunicação, Curitiba, 2009.

${ }^{2}$ Esta pesquisa é financiada pelo Programa de Bolsas Prociência (UERJ/FAPERJ) no triênio 2008-2011.

${ }^{3}$ Este artigo faz parte de uma pesquisa mais ampla que inclui dois tipos de produtos de entretenimento (jogos de computador e seriados de televisão). Neste trabalho, analisaremos os seriados de televisão.

${ }^{4}$ Para um aprofundamento nas práticas sociais de comunicação e entretenimento instigadas pelas TIC, ver RÉGIS, F e PERANI, L. Comunicação e Entretenimento na Cibercultura: repensando as articulaçôes entre lúdico, cogniçâo e tecnologia. In: III Simpósio da ABCiber. São Paulo: ESPM, 2009.

${ }^{5}$ Essa técnica pode ser considerada como uma evolução deste recurso. Em artigo publicado anteriormente sobre o seriado "Perdidos no Espaço" (final dos anos 1960) foi identificado que a seta intermitente contava com mais elementos indicativos (som, fala, encenação, movimento de câmera). 


\section{Referências bibliográficas}

AARSETH, Espen. Cybertext:perspectives on ergodic literature. Baltimore/ London: The John Hopkins University Press, 1997.

ANDERSON, Chris. A Cauda Longa. Rio de Janeiro: Campus/Elsevier, 2006.

BENJAMIN, Walter. "A obra de arte na era de sua reprodutibilidade técnica”. In: Obras Escolhidas: magia e técnica, arte e politica: ensaios sobre a literatura e a história da cultura. 7 ed. São Paulo: Brasiliense, 1994.

CLARK, Andy. Mindware: an introduction to the philosophy of cognitive science. New York/Oxford: Oxford University Press, 2001.

GABLER, Neal. Vida, o filme. Como o entretenimento conquistou a realidade. São Paulo: Companhia das Letras, 1999.

JENKINS, Henry. Cultura da Convergência. São Paulo: Aleph, 2008.

JOHNSON, Steven. Surpreendente! A televisão e o videogame nos tornam mais inteligentes. Rio de Janeiro: Elsevier, 2005.

LÉVY, Pierre. As Tecnologias da Inteligência. Rio de Janeiro: 34 Letras, 1993.

MANOVICH, Lev. Remixing and Remixability, 2005. Disponível em <http://www.manovich.net/DOCS/Remix_modular.doc>

NORMAN, Donald. Things that make us smart. Cambridge: Perseus Books, 1993.

REGIS, Fátima. Tecnologias de Comunicação e Novas Habilidades Cognitivas na Cibercultura. Projeto de Pesquisa apresentado ao Prociência. Rio de Janeiro: UERJ/FAPERJ, 2008.

Seriados de Televisão:

The Incredible Hulk - O Incrivel Hulk (1978-1982) / EUA / Produtora: Universal Television /Emissora original: CBS

Heroes (2006-presente) / EUA/ Produtoras: NBC Universal Television, Tailwind Productions / Emissora original: NBC

Sites consultados:

Orkut - Disponível em: <http://www.orkut.com.br/Main\#Community. aspx?cmm=1601818>. Acesso em: 13 jun. 2009.

Youtube - Disponível em: <http://www.youtube.com/watch?v=XjVdzIg 9nEM\&feature $=$ fvst $>$. Acesso em: 22 jun. 2009

NBC - Disponível em: <http://www.nbc.com/Heroes/games/quiz. shtml>. Acesso em: 15 jun. 2009.

My Space - Disponível em: <http://www.myspace.com/clairebennet>. Acesso em: 20 jun. 2009.

9th Wonders - Disponível em: <http://www.9thwonders.com>. Acesso em: 01/07/2009.

Heroes wiki - Disponível em: <http://heroeswiki.com/>. Acesso em: 23 jun. 2009.

Universal Channel - Disponível em: <http://blog.uc.globo.com/heroes/>. Acesso em: 18 jun. 2009. 